\title{
THE USE OF SOCIAL MEDIA FOR LEARNING ENGLISH
}

\author{
Rahmawati Dwi Handayani, Muh Syafei, Aisayah Ririn Perwikasih Utari \\ Universitas Muria Kudus
}

\begin{abstract}
The objective of the research is to find out the kinds of social media used by fourth semester students of English Education Department of UniversitasMuria Kudus for learning English. The researchers used descriptive qualitative research and the data was collected by the use of questionnaire. The participants are 50 students of English Education Department of UniversitasMuria Kudus. The result showed that social media the students use for learning English are YouTube (94\%),, Instagram (72\%0, WhatsApp (62\%), Twitter (32), Facebook (30\%), Line (10\%), Manwha (6\%), Telegram (2\%), Google (2\%), TikTok (1\%), Cake English App (1\%), Quora (1\%) and Discord (1\%).
\end{abstract}

Key words: social media, learning English.

\section{INRODUCTION}

In the age of the internet, social media has become an important thing in social interaction. Nowadays students are familiar with social media. Social media is internet based tool and platform that develop and share information, it can be a share of words, photos, videos, quotes, others. Social media is also called a tool of information and communication technology used by people to communicate online. The students use social media not only for communication but also social for work and learning. Hudson $(2017 ; 59)$ stated that social media refers to websites and applications that are designed to allow people to share content quickly, efficiently in real time.

Learning is an important thing in the learning process. Learning is a process to get knowledge of a subject or skill by study, experiences and instruction, learning English is a process of getting knowledge about English skill. English skills as broad practically and users skill and users skill of four aspects. They are listening, speaking, writing, reading skills. The studentsof English Education Department must master English well. Learning English is one of the important things for English majors. Most of the students of English Education Department learning English with technology resources as internet media.

Based on the researchers' observation while studying in English Education Department, the researcher found that the students if English Education Department like open their social media. Many students like to open their social media for many different purposes. The students open social media for entertaining and also learn English. the students think that social media has many kinds of resources such as video, photo, caption and other, by this reason, the students using social media for learning English makes the students easy to learn and has a lot of benefits. According to Al Arif $(2019 ; 225)$ social media provides opportunities to increase students' English language skills. Social media provide fun learning resources so that it makes the student's interest learn English language skills by using social media. The others reason the students use social 
media for learning English when students felt difficult and want to improve English skill.

Social media has a positive impact on the students for learning English. Through social media the students can connect and communicate with their friends and other people around the world. Students can increase and exchange information or knowledge by social media with other people. The second is social media provides many updated information or knowledge. By read or watch some information, the students get a lot of information and knowledge from social media. The third is social media make students creative. It because social media has many resources for learning English. They are photos, videos, quotes and others. The students can create their content creatively for example design photos or videos.

Based on the explanation above, this study is to describe the types of social media that the students of fourth semester students of English Education Department of UniversitasMuria Kudus on the use of social media in learning English.

\section{RELATED LITERATURE}

\section{Social Media}

Social media is internet - based tool and platform that increase and share information. It can be share text media (photo, video, audio) words sharing tools information and networking platform. Baruah $(2012 ; 36)$ social media is a media for events, ideas and etc. according to Michael $(2012 ; 11)$ the term social media refers to internet based range and mobile service that allow the users to participate in online exchange, created content or joining community.

Social media is a tool communication technology used by people to communicate online. Social media is famous technology platform used by people of every age and level. Many kinds of social media, for example Facebook, YouTube, Twitter and etc. (Monica and Anamaria, 2014)

Through social media, users can share information and get information quickly and efficiently. Based that social media generally defined form of electronic communication as websites for social networking an through which users can create online communicate information, ideas, personal message or content such as video and photo.

\section{Types of Social Media}

\section{a. Facebook}

Facebook was founded by Mark Zuckerberg in 2004. Facebook is the most popular platform sites that the user use. Based on the survey of we are social shows that Facebook as 2.499 billion users. It shows that many people use social media in their daily life. Facebook allows people to connect with family, friends and people. It allows sharing videos, photos, update status and post with each other. Facebook also can help students in the learning process. Roblyer et all (2010;134-135) state that Facebook is one communication technologies adopted by students to support their educational communication and collaboration. 


\section{b. YouTube}

YouTube is popular video sharing websites were registered users to upload, share and watch the video with other people around the world. YouTube was created by Steve Chen in 2015. YouTube has 2.000 billion users in 2020 . YouTube is available in for everyone who searches and watches many different professionals. Hasemi, Bardine and Ghasemi (2011) explained categories on YouTube. They are Comedy, Sport, Education, Music, News, Travel, Gaming, Film and Animation, People and Vlog, Pet and Animals, Technology and science

c. WhatsApp

WhatsApp is the most important messenger that people use to communicate with others. WhatsApp was found by Brian Aton and Jon Kaum in 2009. Based on the survey we are social around 1620 billion use WhatsApp for their daily life. WhatsApp users can contact other users by personal message, joining group and update story. The users use a number handphone to interact with other users who use WhatsApp. Anamalai (2019) stated that WhatsApp is an application that provides by chat/ group as a platform for extending Learning in the Learning classroom with a small groups. By this theory, WhatsApp can use for learning English. It increasesthe students' ability for writing and reading. WhatsApp also can increase learning enthusiasm.

\section{d. Instagram}

Based on socialmediatoday.com. Instagram is the most popular social media in 2020. Instagram was found by Mike Kringer in 2010. Based on the survey we are social in 2020 shows that Instagram has 1000 billion active users. Instagram, is defined as SNS allows users to create a public profile, connect with other users, view and connected other user in their daily life in real - time. Kenny ( $2015 ; 8)$. Instagram is also photo sharing mobile application and share. Instagram can make connection with other users. Users can follow other users, posting or sharing images or videos with a caption, comments and like post, send personal message by direct message, make a story. Therefore, Instagram, focus on image ad video with the caption or description. Instagram provides L2 learners to produce writing Kelly $(2015 ; 1)$

\section{e. Twitter}

Twitter was found in 2006 by Berners Lee. Based on we are social survey that shows that twitter has 360 million users. Twitter is microblogging users using 140 tweets for their followers, mentions, replies and hashtag. Stech (2015) on Twitter, unregistered users can only read twitter while registered users can write twitter via websites or various applicationsfor mobile devices. Twitter has some account available students of English Education Department learn English. for example @learnEnglih, @learnEnglish_bc, @ellalanguage

\section{f. Line}

Line is one of the platform messenger of the users. Users can do activities like contact personal message to other users or some account, send text, image, video, audio and others. Line was found in 2011 by Jack Dorsey. Nowadays 
around 60 million people use line for their social media accounts. Line uses phone number to add friends. Line also allow the users to add some account related to English account

g. Path

Path was found by Dave Morin in 2010. The user's path around 4 million. Path is a social networking application that allows users to share pictures and messages. The use of path is interested for special places for users with their family and closest friends. The users share photos, videos to other users. Path can load the music are listen, watched movies or books.

h. Telegram

Telegram was found in 203 by Pavel Durov. In 2020 telegram increases the users. It is around 1.5 million. Telegram is a free application multiplatform that allows users to communicate with other. Telegram is available on cell phones, phone devices (Android, Ios, Windows phone and computer peripheral system)

The users can exchange images, videos, stickers, audios and other. According to Selamat (2015) telegram use on process learning during an after class meeting.

a. Announcement

b. Forum

c. Group project report

d. Listening, writing, speaking and reading practice

e. Audioand video input

f. Content and material sharing

\section{Learning English}

Learning English is an activity which is done by the learner during the teaching. learning process to get knowledge. According to Suryono and Hariyanto (2011;9). learning is a process to get knowledge, develop skills, improve behavior and strengthen which is done by students or learners. In the learning process of teaching and learning. Teaching and learning is a two kind process of activities cannot be separated. According to Langit $(2015 ; 8)$ teaching and learning is process between teacher and learner to achieve a certain goal in educations. According to Brown (2010;7-8) learning is getting knowledge of a subject or skill by study, experiences or instruction. Brown also breaks down the component of the definitions as follows: Learning is getting $b$. learning is the retention of knowledge or skill. c, retention implies memory and cognitive organization $\mathrm{d}$. learning involves activities e. learning involves some form of practice $\mathrm{f}$. learning is change behavior

In English subject there are four language skills in the language. According to Brown (2010:224) research and practice in English language is listening, reading, speaking and writing. All of the skills must be mastered by students to achieve learning English language. They are: 


\section{Listening skills}

Listening skills is a process of receiving, constructing meaning form and responding to spoken or nonverbal message to hear something with thoughtful attention.

There are four type of listening skills. They are:

a. Intensive listening is listening for hearing of the words, phenomes, intonation and etc.

b. Responsive listening is listening for short stretch of the language (greeting, command, comprehension check and etc.)

c. Selective is a listening short monologue for several minutes to get information. e.g classroom direction to the radio, news item.

d. Extensive is a way to improve listening fluency

2. Reading skills

Reading is constructing the meaning of words. The readers use eyes to receive written symbol (letter, punctuation, mark and space) and use the brain to convert them into words, sentence and paragraph. Grobe and Stoller $(2013 ; 1)$ reading is an ability someone to draw the meaning and interpret some information

a. There are types of reading skills:

b. Skimming is reading rapidly to get information for the main point

c. Scanning is reading rapidly through a text to find the specific information required

d. Intensive is reading longer text for often, pleasure and overall understanding

e. Extensive is reading shorter text for detailed information

3. Writing skill

According to Wyrick (2011), writing is a productive skill and relative in expressing ideas and explore their thought and feelings. Writing can build students to think critically and deeply to build a good writing. It needs rich vocabulary, clear grammar and spelling along with perfect.so, correct grammar, and punctuation are key in written communication. Writing also must be coherence. To make good writing there are three stages of writing process. They are :

a. Pre writing is put ideas, thought, opinion beginning in the paper. It prepares purpose, content and writing simulation

b. Drafting is after getting ideas, though and opinion then the students must arrange their writing

c. Revising: checking the content clearly. It I changing, adding, leave word to make a good content for the reader.

d. Speaking skill

e. Speaking skill constructs the idea in words to express their minds, idea and thought. People use their vocal and brain to produce sound. Speaking skill is not easy. The students must master grammar, vocabulary and pronunciation to make the others speakers understand what the message of the sound produce. Speaking skills is important for communication. According to Arry $(2000 ; 10)$ there are five components of speaking skills : 
f. Comprehension: it is oral communication requires a subject to respond to speech well to initiate

g. Grammar: the way words are uses to make a sentence. It is needed for students to arrange a correct grammatical sentence into a conversation

h. Vocabulary: vocabulary it is an important thing in speaking skills. Mastering vocabulary means that the students can choose the appropriate diction which is used in communication in any condition

i. Pronunciation: is the way for students' to produce clear language when the students speak. It deals with the phonological process that refers to the component of a grammar made up of the elements and principles that determine how sounds vary and pattern in a language

\section{METHOD}

This research uses a descriptive qualitative research method. The partcipants in this research consist of 50 of fourth semester students of English Education Department of UniversitasMuria Kudus in academic year 2019/2020. To collect the data, the researchers used a questionnaire.

The data collection was done with the following steps. First, preparing the questionnaire sheet. Second, distributing the questionnaire. Third, asking the students to answer the questionnaire sheet. Last, collecting the questionnaire sheet. In analyzing the data, the researchers use the following steps. First, reading and analyzing the questionnaire completed by students. The countingof the total response is put into a table. Next, categorize the questionnaire answer into a percentage. By using the formula of calculating percentage (Healey, 2012;2).

$\mathrm{F}$
$\mathrm{N}=$
$\mathrm{N}$

\section{FINDINGS AND DISCUSSION}

After analyzing the 50 responses from fourth semester students of English Education Department of UniversitasMuria Kudus, the types and percentage of the social media used by students are presented in the following table.

Table 1. The Kinds and Percentage of Social Media to Learn English

\begin{tabular}{cccccc}
\hline No & Kinds of Social Media & Frequency & No & Kinds of Social Media & Frequency \\
\hline 1 & YouTube & $47(94 \%)$ & 8 & Manwha & $3(6 \%)$ \\
2 & Instagram & $36(72 \%)$ & 9 & Google & $2(4 \%)$ \\
3 & WhatsApp & $31(62 \%)$ & 10 & Telegram & $2(4 \%)$ \\
4 & Twitter & $16(32 \%)$ & 11 & TikTok & $1(2 \%)$ \\
5 & Facebook & $15(30 \%)$ & 12 & Quora & $1(2 \%)$ \\
6 & Line & $5(10 \%)$ & 13 & Discord & $1(2 \%)$ \\
7 & Cake English Application & $1(2 \%)$ & & & \\
\hline
\end{tabular}


The researcher finds the dominant social media the students use is YouTube. It shows that the percentage (94\%). This means YouTube is the most favorite social media that the students use for learning English. It is because YouTube provides many resources of videos for learning English skills. So, the students are easy to learn English videos by watching video on YouTube.

The second is Instagram with a percentage (72\%). Instagram is a popular social media. It provides interesting resources. There are videos, captions, photos and others. By this reason, the students can share theirs in Instagram.

With percentage (62\%), WhattsApp is the third favorite of students' social and the students can share their ideas and easy for communication about learning English skills with their friends. Then, Twitter with the a percentage $(32 \%)$. Twitter provides interesting tweets that students can learn and improve their English skill. Next, Facebook with the percentage (30\%) the fifth is Line with the percentage (10\%).

The other social media that the students use for learning English are as follows; Manwha (6\%), Telegram (2\%), Google (2\%), TikTok (1\%), Cake English App (1\%), Quora (1\%) and Discord (1\%)

\section{CONCLUSION AND SUGGESTION}

The result shows that there are many kinds of social media that students use to learn English. The social media that the students use are YouTube, Instagram, WhatsApp, Twitter, Facebook and Line. The students also use other social media to learn English. There are Manwha, Telegram, Google, TikTok, Cake English App, Quora and Discord.

Based on the conclusion above, some suggestions are proposed as follows. First, the information about the kinds of social media that the fourth semester students of English Education Department of UniversitasMuria Kudus use for learning English should be used to help the lecturers manage their teaching and learning process. The lecturers can use social media as a learning tool to help students develop their English language skills. Next, the students should try and use others social media efficiently for learning English. The researchers recommend further researchers to conduct similar research by exploring the other aspects of using social media in Learning English.

\section{REFERENCES}

Al Fath, Muhammad Sandy. (2018). Investigating Gen Z students' perception on the Use Instagram to improve vocabulary. Palangkaraa State Islamic Institute of Palangkaraya English Language Education Department.

Arikunto, Suharsimi. (2010). ProsedurPenelitianSuatuPendekatanPraktek. Jakarta: RienkaCipta 
Arif, TubagusZamZam . (2019). The Use of social media for English Language Learning. An Exploratory study of EFL University Students. Journal of English Langauge Literature and Teaching. 3 (2)

Brown, H Dounglas, (2003). Principles of Language Learning and Teaching. Fifth Edition. New York Pearson Education

Baruah, Trisha Dowerah. (2012). Effective of Social Media as a tool of communication and its potential for technology enabled connections: A micro level study International Journal of scientific and Research Publication. 2 (5)

Firdaus, Muhamad RivaldiJanatan. (2019). The students' perception on YouTube as learning Media in English Education Department UniversitasMuria Kudus. English Education Department UniversitasMuria Kudus Teaher Training and Education Faculty.

Grabe, Wiliam and Stoller, Fredirica L. (2011). Teaching and Researching Reading. London: Pearson Education Limited.

Kelly, R. (2015). An exploration of Instagram to develop ESL learner writing profiency. Published Dissertation. Ulster University

Mismara, Jannaty. (2019). Student's Perception on Using Social Media for Learning English. Banda Aceh. Education and Teacher training ARANNIRI State Islam University.

Monica, and Anamaria, P. (2014). The Impact of social media on vocabulary learning a case study - Facebook. Journal of the University of Oradea. Economic science series. 23(2)

Roblyer, M D, et all. (2010). Findings on Facebook in higher Education. A comparation of collage faculty and students uses and perception of social networking sites. The intenet higher education. 13 (134)

Sakir, Geminastatiti. (2011). Students' Perception on Social Media in Writing class at STKIP MuhammadiyahRappang Indonesia. International Journal of English Linguistics. 6(3)

Sari, RiyantiFatmala. (2018). The Influences of Social Media toward Students English Langauge Learner. Skripsi Published. Palangkaraya: English Education Department of State Islamic Institute of Palangkaraya.

Selly, Irene. (2018). A study on The students' Perception of Social Media to Learn English as a foreign Language. Semarang. English Education Department SoegijaprantaCHatolic University. 
Shidqui, Shabnor. (2016). Social Media its Impact with Positive and Negative aspect. International Journal of Computer and Research. 5 (2)

Sukmadinata and Syaodih Nana. (2016). MetodePenelitianPendiikan. Bandung: RemajaRosdajakarta

The Definiton of Line (https://id.wikipedia.org/wiki/LINE, access on $1 \mathrm{Mei}$ 2020)

The Definition of Twiter (https://id.wikipedia.org/wiki/Twitter, access on 2 Mei 2020)

The Definition of Telegram https://id.wikipedia.org/wiki/Telegram, access on 2 Mei 2020)

The type of Reading (https://www.slideshare.net/SeemeenK/types-of-reading26603800, access on 21 Mei 2020) 